\title{
Granulomatous rosacea-like facial eruption in an elderly man: leukaemia cutis
}

\author{
Aizuri Murad, ${ }^{1}$ Anne Fortune, ${ }^{2}$ Conor $0^{\prime}$ Keane, ${ }^{3}$ Nicola Ralph ${ }^{1}$
}

\begin{abstract}
${ }^{1}$ Dermatology Department, Mater Misericordiae University Hospital, Dublin, Dublin, Ireland

${ }^{2}$ Department of Haematology, Mater Misericordiae University Hospital, Dublin, Ireland ${ }^{3}$ Histopathology Department, Mater Misericordiae University Hospital, Dublin, Dublin, Ireland
\end{abstract}

\section{Correspondence to}

Dr Aizuri Murad, aiz100@hotmail.com

Accepted 11 April 2016

\footnotetext{
To cite: Murad A, Fortune $\mathrm{A}$, $\mathrm{O}^{\prime}$ Keane $\mathrm{C}$, et al. BMJ Case Rep Published online: [please include Day Month Year] doi:10.1136/bcr-2016215568
}

\section{DESCRIPTION}

A man in his 60 s presented with a painful and nonpruritic facial eruption of 1-year duration, which was progressively worsening. He had neither ocular symptoms nor fever. He had been diagnosed with chronic lymphocytic leukaemia (CLL) 15 years prior and treated with an intravenous immunoglobulin, chlorambucil, fludarabine and cyclophosphamide combination, with rituximab on separate occasions, but had suboptimal response. His CLL had been gradually progressive in the later years. Examination of his face revealed erythaematous papules and plaques, most prominent on his nose and upper border of his eyebrows bilaterally (figure 1). There was background erythaema on his forehead and cheeks but there was no telangiectasia, and there were neither pustules nor comedones. His nose was not enlarged and the skin contour of the unaffected areas was within normal limits. He had cervical lymphadenopathy and massive splenomegaly. Skin histology showed a dense nodular lymphoid infiltrate composed of mature small lymphocytes, evident in the upper dermis, with destruction of the adnexal structures (figures 2 and 3). Laboratory investigations revealed leucocytosis $\left(260.2 \times 10^{9} / \mathrm{L}\right.$; mainly lymphocytes with $97 \%$ B-cell), low haemoglobin $\left(8.9 \times 10^{9} / \mathrm{L}\right)$ and low platelets $\left(77.0 \times 10^{9} / \mathrm{L}\right)$. Clinical and histological features were consistent with leukaemia cutis (LC) from B-cell CLL.

LC is known to mimic other inflammatory dermatoses, depending on the site of eruption. CLL patients have been reported to present with facial eruptions mimicking granulomatous rosacea and rhinophyma. This is a less common presentation for CLL patients than for those with Hodgkin's lymphoma, cutaneous lymphoplasmacytoid lymphoma or B-cell lymphoma. ${ }^{1}$ Benedix et $a l^{2}$ reported a case of B-cell CLL that presented with necrobiosis lipoidica-like lesions on the leg in a non-diabetic patient.

LC has been described in patients with myeloid and lymphoid leukaemias, but it is more commonly described in patients with acute myelogenous leukaemia (AML) and T-cell leukaemias. Cutaneous involvement with CLL could be related to a more aggressive histological transformation or disease progression. This was the case for our patient, who had CLL with $17 \mathrm{p}$ deletion. This subset is often associated with poor response to therapy and high rates of Richter transformation. However, there were no blast cells in his skin histology. The prognosis is also less favourable in patients with AML and chronic myeloid leukaemia.

Cutaneous lesions in CLL usually improve with treatment of the underlying disease. There have been reports of cutaneous-specific therapy with

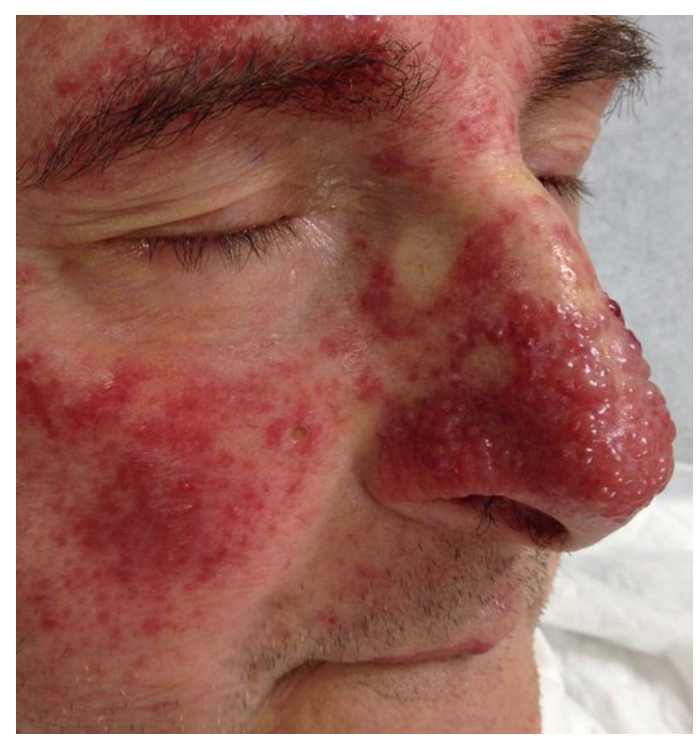

Figure 1 Facial papules and plaques with background erythaema, resembling granulomatous rosacea at presentation.

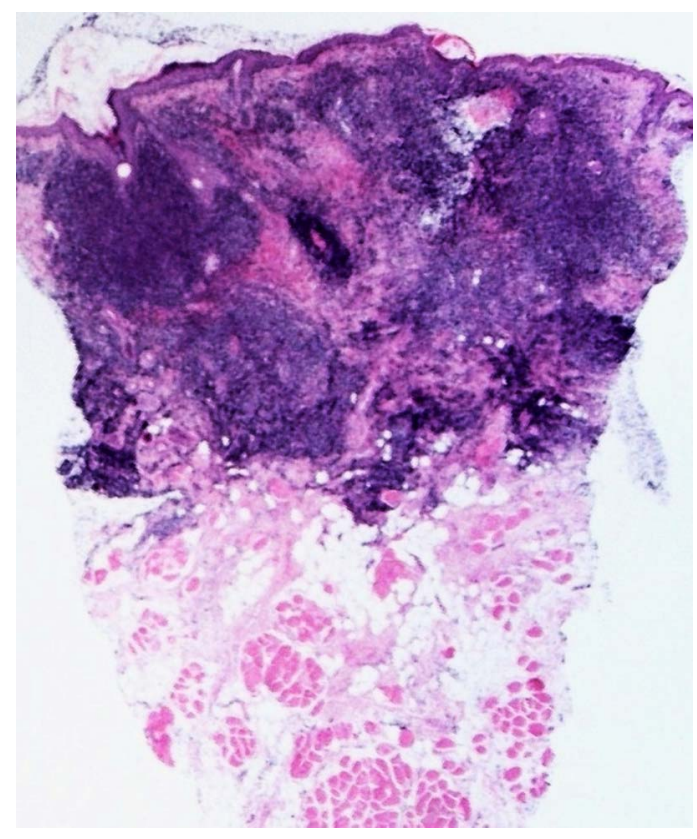

Figure 2 Skin histology demonstrating dense nodular lymphoid infiltrate composed of mature small lymphocytes, evident in the upper dermis, with destruction of the adnexal structures (H\&E stain; original magnification $\times 10$ ).

narrow band UVB, conventional radiotherapy or electron beam irradiation. ${ }^{3}$ Our patient was treated with a phosphoinositide 3-kinase delta inhibitor (Idelalisib) $150 \mathrm{mg}$ twice daily for his underlying 


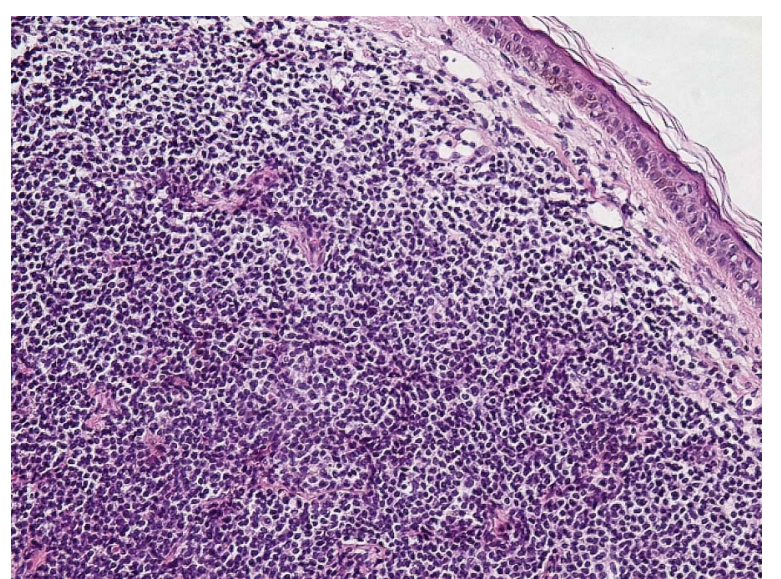

Figure 3 Higher magnification light microscopy demonstrating dense nodular lymphoid infiltrate composed of mature small lymphocytes (H\&E; original magnification $\times 40$ ).

disease, which significantly reduced the induration and erythaema of the lesions after 10 days. He tolerated this medication well and his face remained clear at 8 weeks follow-up.

Acknowledgements The authors thank Dr Jaipreet Singh (Histopathology); Ms Florence Grehan (Clinical photography).

Contributors AM was involved in writing the manuscript. AF was involved in patient care and COK was involved in interpretation of skin histology. All the authors were involved in critical review of the manuscript.

\section{Learning points}

- Leukaemia cutis secondary to either leukaemia or lymphoma commonly mimics other dermatoses. Recognising these variations is crucial as cutaneous involvement of these malignancies has important prognostic implications. Detailed history-taking complemented by a thorough physical examination are crucial steps in making the diagnosis.

- Idelalisib is an effective and well-tolerated treatment for patients with relapsed CLL and p53 mutation. For cases that are less aggressive and limited to the skin, cutaneous directed therapeutic options are available.

Competing interests None declared.

Patient consent Obtained.

Provenance and peer review Not commissioned; externally peer reviewed.

\section{REFERENCES}

1 Barzilai A, Feuerman H, Quaglino P, et al. Cutaneous B-cell neoplasms mimicking granulomatous rosacea or rhinophyma. Arch Dermatol 2012;148:824-31.

2 Benedix F, Metzler G, Röcken M, et al. B-chronic lymphocytic leukaemia in association with necrobiosis lipoidica-like lesions. Br I Dermatol 2005; 153:694-6.

3 Porter WM, Sidwell RU, Catovsky D, et al. Cutaneous presentation of chronic lymphatic leukaemia and response to ultraviolet B phototherapy. $\mathrm{Br}$ I Dermatol 2001;144:1092-4.

Copyright 2016 BMJ Publishing Group. All rights reserved. For permission to reuse any of this content visit http://group.bmj.com/group/rights-licensing/permissions.

BMJ Case Report Fellows may re-use this article for personal use and teaching without any further permission.

Become a Fellow of BMJ Case Reports today and you can:

- Submit as many cases as you like

- Enjoy fast sympathetic peer review and rapid publication of accepted articles

- Access all the published articles

- Re-use any of the published material for personal use and teaching without further permission

For information on Institutional Fellowships contact consortiasales@bmjgroup.com

Visit casereports.bmj.com for more articles like this and to become a Fellow 